

Asia Proceedings of Social Sciences

(APSS)

www.readersinsight.net/APSS

\title{
Impact of Prosocial Motives on Behavior of Employee; Moderated by Helping Instrumentalities
}

\author{
Muhammad Razzaq Athar * \\ University Institute of Management Sciences, Pir Mehr Ali Shah Arid Agriculture University Rawalpindi \\ Pakistan

\section{Hafiza Amtul Hafeez} \\ University Institute of Management Sciences, Pir Mehr Ali Shah Arid Agriculture University Rawalpindi \\ Pakistan
}

*Corrosponding author’s Email: razzaq.arid@gmail.com

Peer-review under responsibility of $4^{\text {th }}$ Asia International Conference 2018 editorial board (http://www.utm.my/asia/our-team/) (C) 2018 Published by Readers Insight Publisher, lat 306 Savoy Residencia, Block 3 F11/1,44000 Islamabad. Pakistan, info@ readersinsight.net

This is an open access article under the CC BY-NC-ND license (http://creativecommons.org/licenses/by-nc-nd/4.0/). 


\section{Research High Iight s}

This research is about the impact of Pro-Social Motives and Helping Behavior with moderating role of Helping Instrumentalities in employees of telecom sector working in Islamabad and Rawalpindi. There is a significant impact of prosocial value motives on helping behavior of and employee, and both helping instrumentalities (tangible and intangible rewards) strengthen the relationship between these variables

\section{Graphical A bst ract}

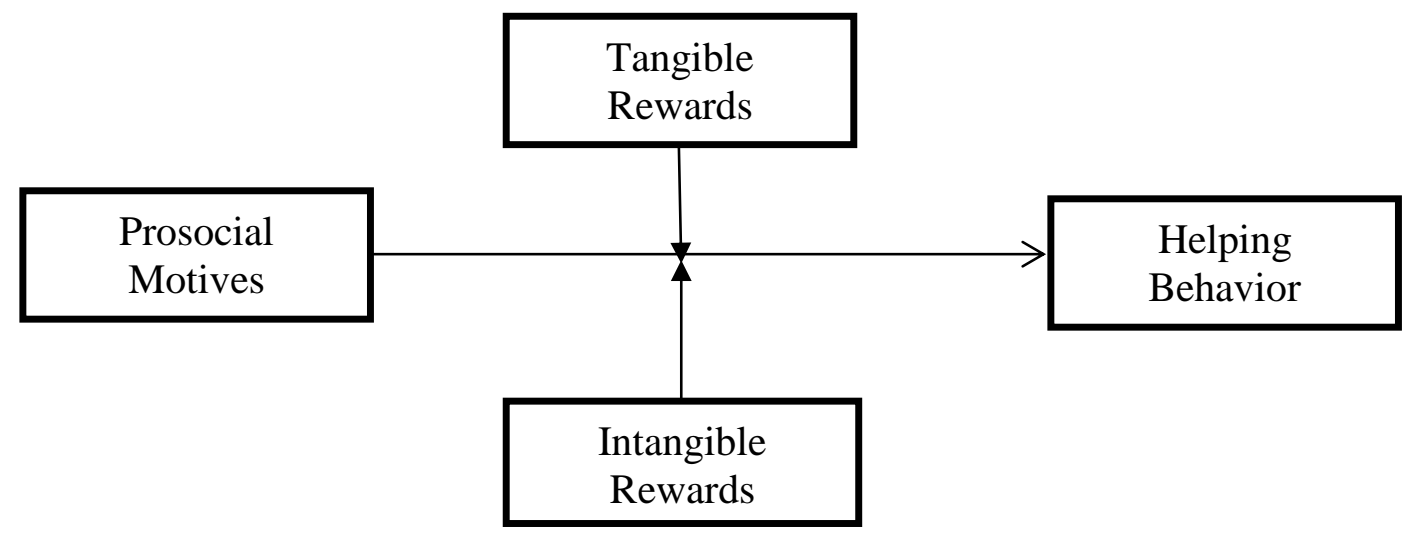

\section{Research Objectives}

- To observe the impact of prosocial motives on helping behavior.

- To explore the impact of helping instrumentalities on helping behavior.

- To find out the impact of prosocial motives on helping behavior with moderating role of tangible rewards as helping instrumentalities.

- To examine the impact of prosocial motives on helping behavior with moderating role of intangible rewards as helping instrumentalities. 


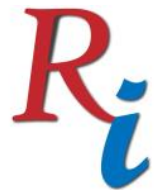

\section{Asia Proceedings of Social Sciences \\ (APSS) \\ www.readersinsight.net/APSS}



\section{Methodology}

Structured Questionaries' is used for this study. We finally use 333 questionnaires received from the managers of telecom sector in Islamabad and Rawalpindi. The sample size determined from the table of (Krejcie and Morgan, 1970).

The survey questionnaire for this study was adopted from the research study of (Allen and Kilmann, 2001) but was modified to some extent, with reference to the Pakistan and items related to employee helping behavior. There were 4 items of intrinsic rewards and 6 items of extrinsic rewards which will be measured. The replies ranged from 1-5. Whereas, 1, denotes strongly disagree, 2 , disagree 3 , for neutral, and 4 , specifies agree and 5 is for strongly agree.

Researcher find out the result of data through SPSS and AMOS software. The information was entered into the SPSS data sheet and then various test were run in order to check out the results. This research study use demographic analysis, correlations, normality and reliability tests and confirmatory factor analysis before testing hypothesis.

\section{Results}

The impact of prosocial value motives (PVM) on helping behavior (HB) was test tested with the moderating role of intangible rewards (IR) as a helping instrumentalities. Regression coefficient of PVM and HB is significant at $b=0.6044$, p-value $>0.0000$ and $b=0.5170$, pvalue > 0.0066 respectively. However, coefficient of interaction term is statistically significant at $b=0.117, p$-value $<0.0256$. Overall model is also significant at $F(3,329)=$ 273.4719, p-value $<0.000$ and this model explains $71.38 \%$ variation in helping behavior. According to the criteria for acceptance of hypothesis the t-value of PVM is 2.7322, and the value of INTR is 7.7024, both values are beyond the limit so therefore hypotheses H1 and H3 are accepted.

For helping instrumentalities. Regression coefficient of PVM and HB is significant at $b=$ $0.701, \mathrm{p}$-value $>0.0000$ and $\mathrm{b}=0.5842, \mathrm{p}$-value $>0.0042$ respectively. However, coefficient of interaction term is statistically significant at $\mathrm{b}=0.1328, \mathrm{p}$-value $<0.0263$. Overall model is also significant at $\mathrm{F}(3,329)=278.4811$, p-value $<0.000$ and this model explains $70.75 \%$ variation in helping behavior. The t-value of PVM is 6.5412, and the value of TR is 2.8841, both values are beyond the limit so therefore hypotheses $\mathrm{H} 2$ and $\mathrm{H} 4$ are accepted. 


\section{Findings}

This research has in general concluded that Pro-Socially encouraged and motivated employees automatically engage themselves in Helping and Serving Behavior towards others in an organization as well as in general (Grant \& Berry, 2011; Grant, 2009; Kamdar et al., 2006). This study addresses the role of prosocial value motives and helping behavior of an employee which plays an vital part in the life of employees in the presence of tangible and intangible rewards as a helping instrumentalities so it helps the employee to know that where they stand and what are their goals and objectives for the betterment of theirorganization.

\section{References}

Allen, T. D., \& Rush, M.C. (1998). The effects of organizational citizenship behavior on performance judgments: a field study and a laboratory experiment. Journal of applied psychology, 83(2), 247.

Grant, A. M., \& Berry, J. W. (2011). The necessity of others is the mother of invention: Intrinsic and prosocial motivations, perspective taking, and creativity. Academy of management journal, 54(1), 73-96.

Grant, A. M., \& Mayer, D.M. (2009). Good soldiers and good actors: prosocial and impression management motives as interactive predictors of affiliate citizenship behaviors. Journal of Applied Psychology, 95(1).

Kamdar, D., McAllister, D. J., \& Turban, D. B. (2006). " All in a day's work": how follower individual differences and justice perceptions predict OCB role definitions and behavior. Journal of Applied Psychology, 91(4), 841.

Krejcie, R. V., \& Morgan, D.W. (1970). Determining sample size for research activities. Educational and psychological measurement, 30(3), 607-610. 